\title{
Mapping the Field of Educational Administration Research: A Journal Citation Network Analysis ${ }^{1}$
}

\author{
Yinying Wang ${ }^{2}$ \\ Georgia State University \\ ywang103@gsu.edu
}

\author{
Alex J. Bowers ${ }^{3}$ \\ Teachers College, Columbia University \\ Bowers@tc.edu
}

\begin{abstract}
:
Purpose: The purpose of this study is to uncover how knowledge is exchanged and disseminated in the educational administration research literature through the journal citation network.

Research Methods: Drawing upon social network theory and citation network studies in other disciplines, we constructed an educational administration journal citation network by extracting all 157,372 citations from 5,359 journal articles in 30 educational administration journals from 2009 to 2013. We then performed social network analysis to visualize the network structure by journal clusters, and quantified journal prominence and interdisciplinarity by calculating Freeman indegree and betweenness, respectively. In addition to journal-to-journal citations, we examined the sources of non-journal citations by citation counts.
\end{abstract}

Findings: The results of journal prominence, interdisciplinarity, and eight journal clusters in the citation network indicate that educational administration, as a porous field, intimately interacts with the sub-fields of education (e.g., urban education and teacher education), other disciplines (e.g., economics, human resources, sociology, and psychology), and the research internationally. In addition to journals as the knowledge source (45.29\%), we also found books $(31.08 \%)$ and reports $(14.98 \%)$ are important citation sources in the educational

\footnotetext{
${ }^{1}$ This document is a pre-print of this manuscript, published in the Journal of Educational Administration. Citation:

Wang, Y., Bowers, A.J. (2016) Mapping the Field of Educational Administration Research: A Journal Citation Network Analysis of the Discipline. Journal of Educational Administration, 54(3), p.242-269. http://dx.doi.org/10.1108/JEA-02-2015-0013

${ }^{2}$ Yinying Wang (ywang103@gsu.edu); Georgia State University, 30 Pryor Street, Room 420, Atlanta, GA 30302-3977. ORCID: 0000-0002-9005-9641

${ }^{3}$ Alex J. Bowers (bowers@tc.edu); Teachers College, Columbia University; Bowers@tc.edu; 525 W. 120th Street, New York, New York 10027. ORCID: 0000-0002-5140-6428, ResearcherID: C1557-201
}

Wang \& Bowers (2016) administration research literature. The most cited books and reports shed light on the knowledge base in the theory, research, and practice of educational administration.

Originality/value: The results of this by far the largest-scale study of educational administration journals present abundant evidence that educational administration is a porous field. This study also presents social network analysis as an alternative method to evaluate journal influence in the educational administration field.

Keywords: citation analysis, bibliometrics, citations (references), citation indexes, social network analysis, educational administration, educational leadership, journal articles, faculty publishing, classification

\section{INTRODUCTION:}

The purpose of this study is to uncover how knowledge is exchanged and disseminated in the educational administration research literature through the journal citation network. Historically, educational administration, as an applied field of leadership in the context of education (Campbell, 1981; Culbertson, 1981; Glatter, 1987; Hodgkinson, 1981; Rowan, 1995; Riffel, 1986), has been termed to have an amorphous nature (Bates, 1980). As Bates summarized, "educational administration is an umbrella term that covers a multitude of ideas and activities representing considerable differences of view between various groups within the profession" (p. 2). Indeed, the multiple theoretical paradigms (see Evers and Lakomski, 2012), inclusive methodologies (see Heck and Hallinger, 2005), and diverse topics in the educational administration research literature (see Murphy et al., 2007) have been viewed paradoxically as, on the one hand, a robust field, while on the other hand, a field lacking coherence and direction (Erickson, 1979; Fitz, 1999; Griffiths, 1997). 
Despite the amorphous nature of educational administration, little is known to date about how this field is socially structured through literature citations, how journals - as a means of knowledge exchange and dissemination (Davis, 2014) —interact with one another, and to what extent the research realm is open to external ideas from other disciplines. Not long after establishing the field of educational administration in 1960s (Evers and Lakomski, 2012; Hallinger and Chen, 2015; Oplatka, 2009), Haller (1968) noted the field's interdisciplinary ideology by stating that education and sociology were the most influential disciplines that contributed to the educational administration scholarship. Half a century later, however, there has been very limited literature investigating the current interdisciplinary boundaries in the field. Thus, we take a reflective look at the literature by uncovering the social infrastructure of the citation patterns in educational administration journals. We used the journal citation network as a proxy to reveal the social infrastructure of educational administration, as peer-reviewed academic journals play a critical role in disseminating and advancing knowledge (Davis, 2014; Haller, 1968). Moving beyond citation counts, we drew on the theoretical lens of social network theory to gauge prominence and interdisciplinarity across the journals that make up the research frontiers of educational administration, applying fresh insights on how educational administration journals interact with one another through their citations and thus contribute to the knowledge dissemination and the dynamics of the field. Further, to translate research knowledge into the professional practice of leading schools, it is important to understand the increasingly extensive knowledge base - described by Oplatka (2009) as "the big bang" (p. 15) referring to the limitless expansion of the educational administration field. Therefore, we also aimed to uncover the current knowledge base of the field by examining the major knowledge sources in the educational administration research literature citations. Overall, with a focus on mapping and understanding the linkages of citations between journals in educational administration - a chain of who is citing whom, this study addresses the following three questions:

- Which journals have high prominence in the educational administration field?

- Which journals have high interdisciplinary outreach in the educational administration field?
- What are the major knowledge sources in the educational administration research literature citations?

\section{RELATED LITERATURE}

The citation patterns in the literature manifest the knowledge structure of a discipline (Narin et al., 1972; Price, 1965). Thanks to the constant pursuit of knowledge, as a relatively self-contained branch of knowledge, a discipline never remains static in terms of the structural boundaries of the knowledge that the discipline represents (Chakraborty et al., 2014; Straus, 1973). Further, the knowledge in a discipline, instead of being conceptualized as abstract ideas held individually and invisible to others, is socially connected through citations (Barnett et al., 2011; Brughmans, 2013). As Price (1965) noted, citation patterns reveal "the nature of the scientific research front" (p. 6). An example is Shwed and Bearman's (2010) study that examined how a scientific community formed consensus over time on debated areas of research-such as the suspected carcinogenicity of cigarette smoking-by observing the citation network structure changes over time. Another notable example is Narin et al.'s (1972) study on the interrelationships of the scientific journals in mathematics, physics, chemistry, biochemistry, and biology. By mapping which journal cited which other journals most frequently, Narin et al. demonstrated the bridging roles of the journals Science and Nature between physics and biology, and the relationships between disciplines: biology $\rightarrow$ biochemistry $\rightarrow$ chemistry $\rightarrow$ physics $\rightarrow$ mathematics and statistics (i.e., biology cited biochemistry most frequently, biochemistry cited chemistry most frequently, and so forth). Therefore, the analyses of journal citation linkage patterns shine a unique light on a discipline's inward focus and outward reach.

In this article, we follow Haller's (1968) view that deems education as a discipline, like other disciplines such as sociology, economics, and anthropology. Haller (1968) defined disciplines as "clusters of related perspectives on social phenomena in which, as it were, the between-group variance is greater than that within groups" (p. 66). In other words, the differences between disciplines-such as education and economics - are greater than the differences between the sub-fields of education-such as educational administration and teacher education. In the educational administration literature, while the terms 
"discipline" and "field" have been used interchangeably to describe educational administration (e.g., Bush, 1999; Evers and Lakomski, 2012; Haller, 1968; Murphy et al., 2007; Richardson and McLeod, 2009), scholars perceived that educational administration is an applied field in the context of education (Campbell, 1981; Culbertson, 1981; Glatter, 1987; Hodgkinson, 1981; Rowan, 1995; Riffel, 1986). As a corollary, we consider education as a discipline, and educational administration as an applied sub-field in the discipline of education.

In the educational administration field, a handful of citation studies have advanced our understanding of the history and development of the field. Haller's (1968) study was the first citation analysis in the educational administration field. He concluded the interdisciplinary ideology of the field after examining all 657 citations of the articles published in Educational Administration Quarterly's (EAQ) first three volumes, as well as the publishing authors' academic department affiliation and academic training. Predicated on the assumption that "disciplines represent clusters of related perspectives on social phenomena in which, as it were, the between-group variance is greater than that within groups" (p. 66), Haller found that education and sociology were the two disciplines that substantially contributed to educational administration, followed by psychology and social psychology, political science, economics, anthropology, and others.

Another early citation study was conducted by Campbell (1979), looking into what journals were mostly cited by 238 articles published in EAQ's first fourteen years, spanning from 1965 to 1978. Administrative Science Quarterly, the leading journal of administration across disciplines, was EAQ's topcited journal, followed by EAQ itself, Phi Delta Kappan, and the Journal of Educational Administration. To further explore how EAQ articles related to other disciplines, Campbell examined how often Administrative Science Quarterly cited EAQ, and lamented that it was "a little embarrassing" (p. 10) because none of over 4,000 references in Administrative Science Quarterly cited EAQ articles. He concluded that the impact of $E A Q$ articles on the literature in other disciplines appeared to be limited.

Haas and his colleagues (Haas et al., 2007) continued part of Campbell's study (1979) by examining EAQ article citation patterns to gauge $E A Q$ 's influence on education literature from 1979 to 2003. Overall, EAQ had "a broad, but mostly shallow, influence" (Haas et al., 2007, p. 500) on the journals primarily in the United States. In addition, $72 \%$ of the 349 journals citing $E A Q$ articles were not directly pertinent to education (e.g., American Psychologist and Harvard Journal on Legislation). After searching for all citations to $E A Q$ articles in the Web of Science database, Hass et al. reported 15 core journals that $E A Q$ had a consistent influence on, according to the number of citations to $E A Q$ articles. Yet one limitation of Haas et al.'s study, as the authors acknowledged, is that the Web of Science database does not contain some prominent education journals, such as the Journal of Educational Administration and Educational Researcher.

A recent citation study in the educational administration field was conducted by Richardson and McLeod (2011). In addition to $E A Q$, the journal that has been repeatedly analyzed in the previous studies, Richardson and McLeod added Journal of School Leadership (JSL) to their study because they argued that JSL was another top journal in educational administration. However, as Cherkowski, Currie, and Hilton (2011) critiqued, Richardson and McLeod did not provide the empirical evidence to support their decision on including $J S L$ in their study. By counting how many times $E A Q$ and $J S L$ cited other journals, Richardson and McLeod recommended educational administration authors to publish in those most cited journals in order to get noticed by the top journals in educational administration. Further, Richardson and McLeod differentiated the audience of EAQ and JSL by comparing the two journals' list of most cited journals: $E A Q$ focused on empirical research, theory, and philosophy; whereas JSL focused on practice, practitioners, and knowledge application.

In contrast to using citations as a proxy to examine journals, Cherkowski et al. (2011) administered a survey as a mode of inquiry in educational administration journals. Cherkowski et al. used a survey instrument-Active Scholar Assessment-to collect publishing authors' ratings on journal quality and the level of journal awareness on a five-point Likert scale. While Cherkowski et al.'s study examined a relatively comprehensive list of educational administration journals, their study, as Cherkowski et al. noted, was subject to the small 
sample size and relied heavily on the perceptions of educational administration researchers to determine a journal's influence and impact.

Overall, the above journal studies are valuable as they allow us to understand the history and development of educational administration. Yet an inherent limitation across the previous educational administration journal studies, specifically the citation studies, is that they focused solely on the pair of journals (i.e., Journal A cited Journal B). This exclusive focus runs the risk of oversimplifying the relationships between journals by ignoring the chains of who is citing whom. Consider Journal A cited Journal B; meanwhile, Journal B cited Journal C, and Journal C cited Journal D. These citations generate a chain of Journal $\mathrm{A} \rightarrow \mathrm{B} \rightarrow \mathrm{C} \rightarrow \mathrm{D}$, depicting how the knowledge is exchanged and disseminated through citations. Accordingly, journals have been considered as an "invisible hand" (Wang et al., 2011, p. 70) in knowledge creation and dissemination in academia. For this reason, to overcome the limitations in the extant educational administration journal studies, we draw from social network theory to construct a journal citation network of educational administration in order to uncover how the knowledge of educational administration is exchanged and disseminated through citations.

\section{JOURNAL CITATION NETWORK}

Before building a journal citation network in educational administration, we first introduce social network theory, followed by a review of the literature using this theory in the journal studies in other disciplines in an effort to provide a framing for the usefulness of this perspective in understanding journal influence on the educational administration field. We then introduce two centrality measures that quantify journals' influence based on the journals' structural position in the journal citation network.

\section{Social Network Theory}

The network is composed of actors (also called vertices or nodes) and ties (also called links or relationships) (Borgatti and Ofem, 2010). Social network theory holds that the actors are not dependent from one another, but interdependent through the ties serving as the conduit for resource exchange (Burt, 1982; Degenne and Forse, 1999; Wasserman and Faust, 1994). By this view, the presence or absence of ties and the strength of ties exert influence on resource flow in the network and thereby hinder or enhance individual actor performance and collective performance of the network as a whole (Borgatti and Foster, 2003; Burt, 1982). By performing social network analysis, each actor's structural position in the network can be quantified through analyzing the patterns of ties in order to measure to what extent resources flow to and from each actor (Borgatti and Everett, 1992; Burt, 1976, 1980).

Social network theory has been increasingly applied in the educational administration research. In Daly's (2010) book titled Social Network Theory and Educational Change, he drew attention to the social relational ties among teachers and leaders, and argued that those relational ties were a more potent force than strategic plans to facilitate or impede education reform. A shift from the focus on individuals and their attributes to a focus on a larger social infrastructure, according to Daly (2010), sheds light on an enriched understanding of educational administration and policy making. For instance, at the school level, the more central a school principal was in the school's adviceseeking network, the more robust was the school' innovative climate (Moolenaar et al., 2010). In the arena of policy making, an elite group of wealthy individuals and their affiliated philanthropic organizations were far more influential than average voters in the charter school policy making network in the state of Washington (Au and Ferrare, 2014). Taken together, those influential actors occupy a central location in the social networks by building dense incoming and outgoing ties, and thus gain opportunities to access diverse resources and broker the flow of resources in the network (Kilduff and Krackhardt, 2008).

\section{Citation Network Analysis}

The conceptual lens of social network theory and the analytical framework of social network analysis have also been used in journal citation studies across disciplines. Citation network analysis has been frequently used as an analytical tool in bibliometrics (Borgman, 1989). In the journal citation networks, journals are conceptualized as vertices, and citation relationships between journals as directional ties - the tie arrows show where the citation ties originate and end. To illustrate such a network, we provide a hypothetical journal citation network as an example in Figure 1, which consists of seven vertices (Journal A, $\mathrm{B}, \mathrm{C}, \mathrm{D}, \mathrm{E}, \mathrm{F}$, and $\mathrm{G}$ ) and nine directional ties (Journal $\mathrm{A} \rightarrow \mathrm{B}, \mathrm{A} \rightarrow \mathrm{D}, \mathrm{A} \rightarrow \mathrm{E}, \mathrm{C} \rightarrow \mathrm{A}, \mathrm{C} \rightarrow \mathrm{B}, \mathrm{E} \rightarrow \mathrm{B}, \mathrm{F} \rightarrow \mathrm{A}$, 


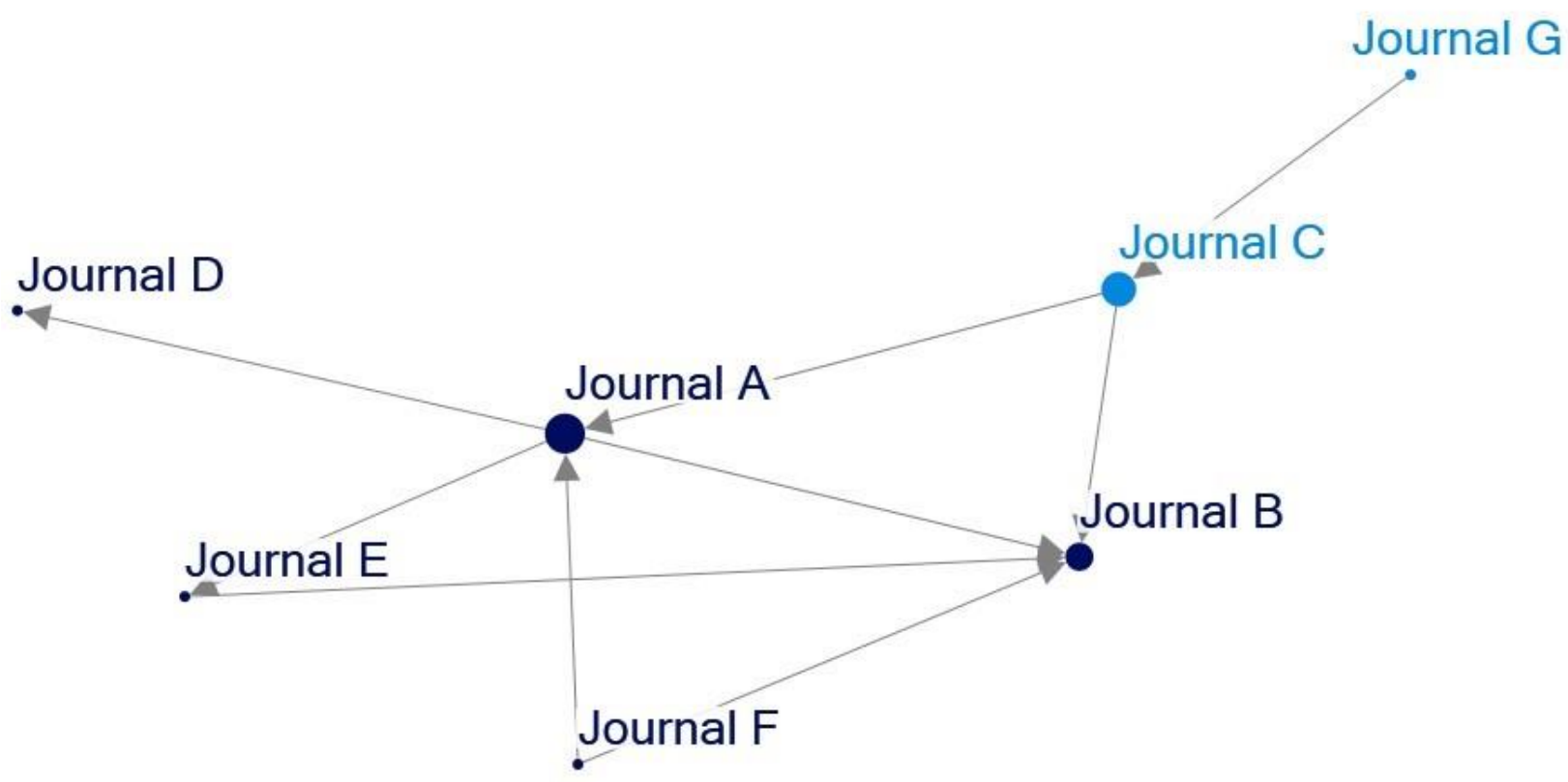

Figure 1 A hypothetical example of journal citation network which consists of seven vertices (Journal $\mathrm{A}, \mathrm{B}, \mathrm{C}, \mathrm{D}, \mathrm{E}, \mathrm{F}$, and $\mathrm{G}$ ) and nine directional ties (Journal $\mathrm{A} \rightarrow \mathrm{B}, \mathrm{A} \rightarrow \mathrm{D}, \mathrm{A} \rightarrow \mathrm{E}, \mathrm{C} \rightarrow \mathrm{A}, \mathrm{C} \rightarrow \mathrm{B}, \mathrm{E} \rightarrow \mathrm{B}$, $\mathrm{F} \rightarrow \mathrm{A}, \mathrm{F} \rightarrow \mathrm{B}$, and $\mathrm{G} \rightarrow \mathrm{C}$ ). Among seven journals, Journal $\mathrm{B}$ is the most prominent journal with the highest Freeman indegree, indicating Journal B has the most incoming ties and thereby is mostly sought by others. Journal A has the most interdisciplinary outreach with the highest betweenness, because Journal A's structual location is on the shortest path from Journal C to D, F to E, and F to D. Moreover, the two colors of vertices (dark blue and light blue) indicate two clusters of journals, according to the result of network cluster analysis by applying the Givan-Newman algorithm (2002).

$\mathrm{F} \rightarrow \mathrm{B}$, and $\mathrm{G} \rightarrow \mathrm{C}$ ). For example, Journal $\mathrm{B}$ is cited by Journal $\mathrm{A}, \mathrm{C}, \mathrm{E}$, and $\mathrm{F}$, so we see four directional ties pointing to Journal $\mathrm{B}(\mathrm{A} \rightarrow \mathrm{B}, \mathrm{C} \rightarrow \mathrm{B}, \mathrm{E} \rightarrow \mathrm{B}$, and $\mathrm{F} \rightarrow \mathrm{B})$. From the standpoint of social network theory, citations ties provide the social infrastructure for the knowledge to flow to and from journals, and thus the journals (Journal A and B in the hypothetical example) in the center of the citation network exert higher impact than those in the peripheral on the knowledge exchange and dissemination. As a result, how central a journal is in the network would help us understand how much impact a journal has on knowledge exchange and dissemination. To quantify the journals' structural position-how central a journal is located-in the citation network, we employed Freeman indegree centrality to examine educational administration journals' prominence, and betweenness centrality to examine the journals' interdisciplinarity. In the following section, we highlight the definitional distinctions between these two centrality measures and present the rationale for using Freeman indegree and betweenness in the present study.

First, Freeman indegree (Freeman, 1979) refers to the degree of incoming relational ties a vertex (journal in this case) has in the network. In journal citation networks, high-indegree journals are denoted as "highly prominent journals" because they have more incoming citation ties than low-indegree journals (Polites and Watson, 2009). In the hypothetical journal citation network illustrated in Figure 1, Journal B has the highest Freeman indegree because it has the most incoming citation ties, indicating that Journal B is mostly sought by other journals for knowledge in the 
network. More importantly, Freeman indegree not only measures how many journals cite a given journal, but also considers the citation tie strength (i.e., citation frequency counts). If the Journal $\mathrm{A} \rightarrow \mathrm{B}$ citation tie occurs repeatedly, then the repeated citation ties are converted to tie strength for Freeman indegree calculation. Thus, using Freeman indegree as an indicator of journal prominence is an improvement upon the previous methods in the existing educational administration journal studies that relied exclusively on citation frequency counts.

Second, betweenness, as the name suggests, quantifies the degree to which a given vertex (journal in this case) functions as a boundary spanner of knowledge flow in the network according to the vertex's structural position between two other vertices on the shortest path (Freeman, 1977). In Figure 1, Journal A has the highest betweenness because Journal $\mathrm{C}$ only cites Journal $\mathrm{D}$ through the path of Journal $\mathrm{C} \rightarrow \mathrm{A} \rightarrow \mathrm{D}$, and Journal $\mathrm{F}$ only cites Journal $\mathrm{E}$ through the path of $\mathrm{F} \rightarrow \mathrm{A} \rightarrow \mathrm{E}$. The removal of Journal A would lead to a fragmented network, constraining the knowledge exchange and dissemination. As a result, in contrast to the highest indegree Journal B being the most sought journal by others, Journal A has the highest betweenness, functioning as a boundary spanner by standing on the shortest path from journal $\mathrm{C}$ to $\mathrm{D}$ and journal $\mathrm{F}$ to $\mathrm{E}$.

The distinctive feature of betweenness - a numerical measure of the degree a journal stands between other journals in a citation network-provides an additional and often under-researched perspective on a journal's influence in terms of bridging the knowledge between journals. It has been difficult to examine a journal's interdisciplinarity, given the ambiguous categorization of journals' subject (Bensman, 2001) and multiple intellectual categories, such as the fact that journals are published in different countries and are owned by publishers (Leydesdorff and Bensman, 2006). Yet interdisciplinarity is essential because new knowledge may be created at the borders of disciplines (Zitt, 2005), as exemplified by the interdisciplinarity of the field of nanotechnology which has evolved at the interface between applied physics, chemistry, and material sciences (Leydesdorff, 2007). Leydesdorff (2007) argued that betweenness is a more effective measure of a journal's interdisciplinarity in comparison with the classification of journal articles. In fact, the previous attempts to provide empirical evidence of the interdisciplinary nature of educational administration have proved to be an arduous task, because educational administration encompasses the literature from an array of research areas, spanning from economics and finance, political science, sociology, psychology, philosophy, personnel, to law (Bates, 1980; Campbell, 1979; Haller, 1968; Murphy et al., 2007). We thereby follow Leydesdorff's (2007) suggestion of using betweenness to measure journal interdisciplinarity, exploring how journals play a brokerage role in the knowledge exchange and dissemination in educational administration.

In sum, we draw from the citation network studies in other disciplines, and applied Freeman indegree and betweenness centrality measures in our analysis of the educational administration journal citation network. In doing so, we not only build upon the past work that has focused on journal article counts and rankings in the educational administration field, but also examine how journals interact in the citation network by addressing the following three research questions: 1) Which journals have high prominence in the educational administration field? 2) Which journals have high interdisciplinary outreach in the educational administration field? and 3) What are the major knowledge sources in the educational administration research literature citations?

\section{METHODS}

This study uses social network analysis to examine the citation network structure across the peer reviewed journals in educational administration. In this section we first detail the selection of journals included in the analysis. Second, we explain the procedure of extracting citations from journal article references and categorizing all citations according to the sources of citation. Third, we use social network analysis to quantify journal prominence and interdisciplinarity by calculating Freeman indegree and betweenness, respectively. As the citation ties shape the relational structure of the educational administration journal citation network, it is pivotal to decide which journals should be included in the present study. We start with the procedure of journal selection.

\section{Journal Selection}

Following the recommendations of the literature in journal citation studies noted above, to construct a journal citation network, we compiled a list of journals that have been examined in the previous journal 
studies in educational administration. We examined each of 48 journals in Cherkowski et al.'s (2011) study, finding that while the majority of the journals are still in print, unfortunately a few have ceased publication; for seven journals we lacked access through three different university libraries; some allowed only restricted access to certain issues which kept us from including the journals in the present study. We therefore excluded those journals, as noted in Appendix. By doing so, we finalized a list of 30 journals for which we had full data on the entire set of citations for each article within the 30 journals from 2009 through 2013. This resulted in $n=157,372$ citations across $N=5,359$ articles from the 30 journals over the five-year period. These 30 journals make up the central corpus of what we term here the Educational Administration Journal Dataset.

\section{Citation Data Extraction and Categorization}

To extract the journal citation data, we first created a script in the Java programming language to extract all citations listed in all articles published in the 30 citing journals' references from 2009 to 2013. We then, according to the citation sources, categorized each citation into journal citation (the authors cited journals) and non-journal citation (the authors cited non-journal sources such as books and reports). The data on journal citations were then converted into a data language file format that can be read into UCINET (Borgatti et al., 2002) for the network construction and analysis. Non-journal citations were then further categorized into sub-groups according to citation sources. It is worth noting that the citations in Educational Research and Reviews, an open-access Turkish journal, had multiple abbreviations for the same journal (e.g., Am. Educ. Res. J, Ame. Educ. Res. J, Amer. Educ. Res. J, and American Educ. Res. $J$ for American Educational Research Journal). To ensure that citation counts between journals were captured correctly, we created a thesaurus for matching multiple journal abbreviations to their corresponding journal names.

\section{Data Analysis}

Following the recommendations of the previous literature (Polites and Watson, 2009), we constructed a journal citation network in which each vertex represents a unique journal, the tie represent the journal-to-journal citation, the tie strength represents the frequency of journal-to-journal citations (e.,g., if Journal A cited B 10 times, then the A $\rightarrow$ B tie strength is 10), and the tie arrow starts from a citing journal and ends with a cited journal. We then calculated Freeman indegree centrality and betweenness centrality to identify the influential journals in educational administration. As noted earlier, Freeman indegree quantifies a journal's prominence (Polites and Watson, 2009). Moreover, among many betweenness centrality calculation methods, we applied Brandes' (2001) algorithm to compute betweenness centrality in the current study. This is primarily because Brandes' algorithm is particularly effective in large-scale network analysis as it is more efficient computationally than comparable options. Selfcitations (i.e., the citing journal and cited journal are the same) were eliminated before the calculation of Freeman indegree and betweenness, because selfcitations created self-loops which have miniscule impact on the results of the two centrality measures.

To further reveal the social structure of the educational administration journal citation network, we applied the Givan-Newman algorithm (Givan and Newman, 2002) by using NodeXL, a social network analysis and visualization software package, to visually map the educational administration research literature by illustrating how journals cluster in the network. With a focus on vertex betweenness, the Givan-Newman algorithm is a hierarchical agglomeration approach to detect tightly knit groups in the network so that the vertices within the clusters are densely connected, and the connections between clusters are relatively loose. By using the Givan-Newman algorithm, we were able to visualize the educational administration journal citation network to corroborate graphically the results of high-betweenness journals in the network as a representation of interdisciplinarity.

Among the 157,372 citations extracted for the present study, journals were not the sole source of citations. Rather, a variety of citation sources were seen in our Educational Administration Journal Dataset. To fully capture the citation patterns, for non-journal citations, we created a Java script to further categorize those citations into sub-groups based on the source of citations. We then extracted the most cited books and reports according to citation frequency counts in order to examine the extent that the knowledge from nonjournal sources was disseminated across the educational administration field. 


\section{RESULTS}

The purpose of this study is to uncover how knowledge is exchanged and disseminated in the educational administration research literature through the journal citation network. In this section, we first present all of the citation sources in our Educational Administration Journal Dataset. We then describe the overall relational structure of the educational administration journal citation network, followed by the results of our calculations of journal prominence and interdisciplinarity. We end this section by presenting the results of the most cited books and reports in the educational administration research literature. We then turn to a discussion of the results.

\section{Diverse Citation Sources in Educational} Administration

Overall, a wide variety of citation sources were found in the educational administration research literature. The 157,372 citations represent a broad range of sources across the academic and non-academic literature, including peer reviewed journals, books, reports, conference papers, dissertations, media, and unpublished manuscripts. Table 1 presents the counts and frequencies of the different sources of citations. Three sources of citations-journals, books, and reports-accounted for the majority of citations (91.35\%). Specifically, 71,279 (45.29\%) citations came from journals, followed by book citations $(n=$ $48,911,31.08 \%)$ and report/working paper citations ( $n$ $=23,570,14.98 \%)$. The citations from conferences $(1.43 \%)$, dissertation/thesis $(1.24 \%)$, and media $(1.08 \%)$ were sparse.

\section{The Educational Administration Journal Citation Network}

Our findings show that the educational administration journal citation network is vast, connecting a universe of 6,382 unique journals across 71,279 journal-tojournal citation ties. Not all 6,382 journals received equal attention in the educational administration research literature. On one end of the spectrum, a vast majority of journals (5,690 journals, $89.18 \%)$ were cited only once by one of the 30 citing journals included in our analysis. Here, in Figure 2, we provide a network visualization for the full journal citation network across all 6,382 journals and 71,279 citation ties. The 6,382 journals were grouped into ten clusters by applying the Givan-Newman algorithm. However, as demonstrated in the previous literature on citation networks (e.g., Shwed and Bearman, 2010), while
Figure 2 provides a means to visualize the entire network, such a visualization becomes difficult to interpret when only $10.82 \%$ of the 6,382 journals received more than one citation.

Figure 3 provides a means to interpret the social structure of the journals that were cited at least 50 times by one of the 30 citing journals in our Educational Administration Journal Dataset. In comparison with Figure 2, a threshold of tie strength $\geq$ 50 (citation frequency is greater than or equal 50) in Figure 3 helps us to explicitly identify the shared aims and scope of the journals in each cluster. The network cluster analysis identified eight clusters (visualized in eight colors in Figure 3) of the journal citation network. Journal interdisciplinarity is represented by the vertex size, with a larger vertex indicating higher betweenness, which as noted earlier, represents the journals' interdisciplinary outreach. As shown in Figure 3, the journals that make up the core of the peer reviewed academic journal knowledge base in educational administration research are noted in light blue. The journals in this cluster include not only educational administration journals such as Educational Administration Quarterly (EAQ), the Journal of Educational Administration (JEA), and Journal of School Leadership (JSL), but also education research journals such as the American Educational Research Journal and Teachers College Record. Further, in Figure $3 \mathrm{~b}$ which highlights the citation frequency (i.e., the strength of tie), the strong citation ties - as evidenced by the thick ties - suggest the close relationship between the three educational administration journals: EAQ, JEA, and JSL.

The network cluster analysis also identified other journal clusters that connect to the core journals of educational administration (light blue, center), indicating related but separate domains of knowledge. This includes (going clockwise around Figure 3) an urban education cluster (light green, right), economics (dark blue, lower right), psychology and general education research (dark green, lower left), practitioner literature such as NASSP Bulletin (lime green, left), education policy and research in the United Kingdom (red, upper left), which interacts with the international educational administration journal cluster (orange, top). However, the education evaluation journal cluster (yellow, upper right. Journal of Personnel Evaluation in Education changed its name to Educational Assessment, Evaluation and 
Table 1 Sources of Citations in the Educational Administration Field $(n=157,372)$

\begin{tabular}{|c|c|c|c|}
\hline Source & Citations & $\%$ & Examples \\
\hline Journal & 71,279 & $45.29 \%$ & $\begin{array}{l}\text { Educational Administration Quarterly, } \\
\text { Journal of Educational Administration }\end{array}$ \\
\hline Book/chapter & 48,911 & $31.08 \%$ & $\begin{array}{l}\text { Book of A New Agenda for Research in } \\
\text { Educational Leadership }\end{array}$ \\
\hline Report/working paper & 23,570 & $14.98 \%$ & $\begin{array}{l}\text { Reports or working papers from U.S. } \\
\text { Department of Education, U.S. Census } \\
\text { Bureau, Organization for Economic } \\
\text { Cooperation and Development, National } \\
\text { Bureau of Economic Research, and } \\
\text { UNESCO }\end{array}$ \\
\hline Citations in foreign language & 5,548 & $3.53 \%$ & $\begin{array}{l}\text { Citations in French, Spanish, Portuguese, } \\
\text { and Chinese }\end{array}$ \\
\hline Conference & 2,247 & $1.43 \%$ & $\begin{array}{l}\text { Papers presented at University Council } \\
\text { for Educational Administration } \\
\text { conventions and American Educational } \\
\text { Research Association annual meetings }\end{array}$ \\
\hline Dissertation/thesis & 1,948 & $1.24 \%$ & Dissertation and thesis \\
\hline Media/newspaper/magazine & 1,696 & $1.08 \%$ & $\begin{array}{l}\text { The New York Times, the Guardian, the } \\
\text { Washington Post, and Bloomberg } \\
\text { Businessweek Week }\end{array}$ \\
\hline Legislature/act/statute & 1,367 & $0.87 \%$ & $\begin{array}{l}\text { No Child Left Behind Act of 2001, } \\
\text { Brown v. Board of Education, } 347 \text { U.S. } \\
483 \text { (1954) }\end{array}$ \\
\hline Unpublished manuscript & 388 & $0.22 \%$ & $\begin{array}{l}\text { Unpublished manuscript, manuscript in } \\
\text { preparation, manuscript under review. }\end{array}$ \\
\hline Incomplete citations & 261 & $0.17 \%$ & $\begin{array}{l}\text { Citations that are missing journal or book } \\
\text { names. }\end{array}$ \\
\hline Other & 157 & $0.10 \%$ & $\begin{array}{l}\text { Personal communication, listserv, motion } \\
\text { pictures, documentaries, and dictionary. }\end{array}$ \\
\hline Total & 157,372 & $100 \%$ & \\
\hline
\end{tabular}




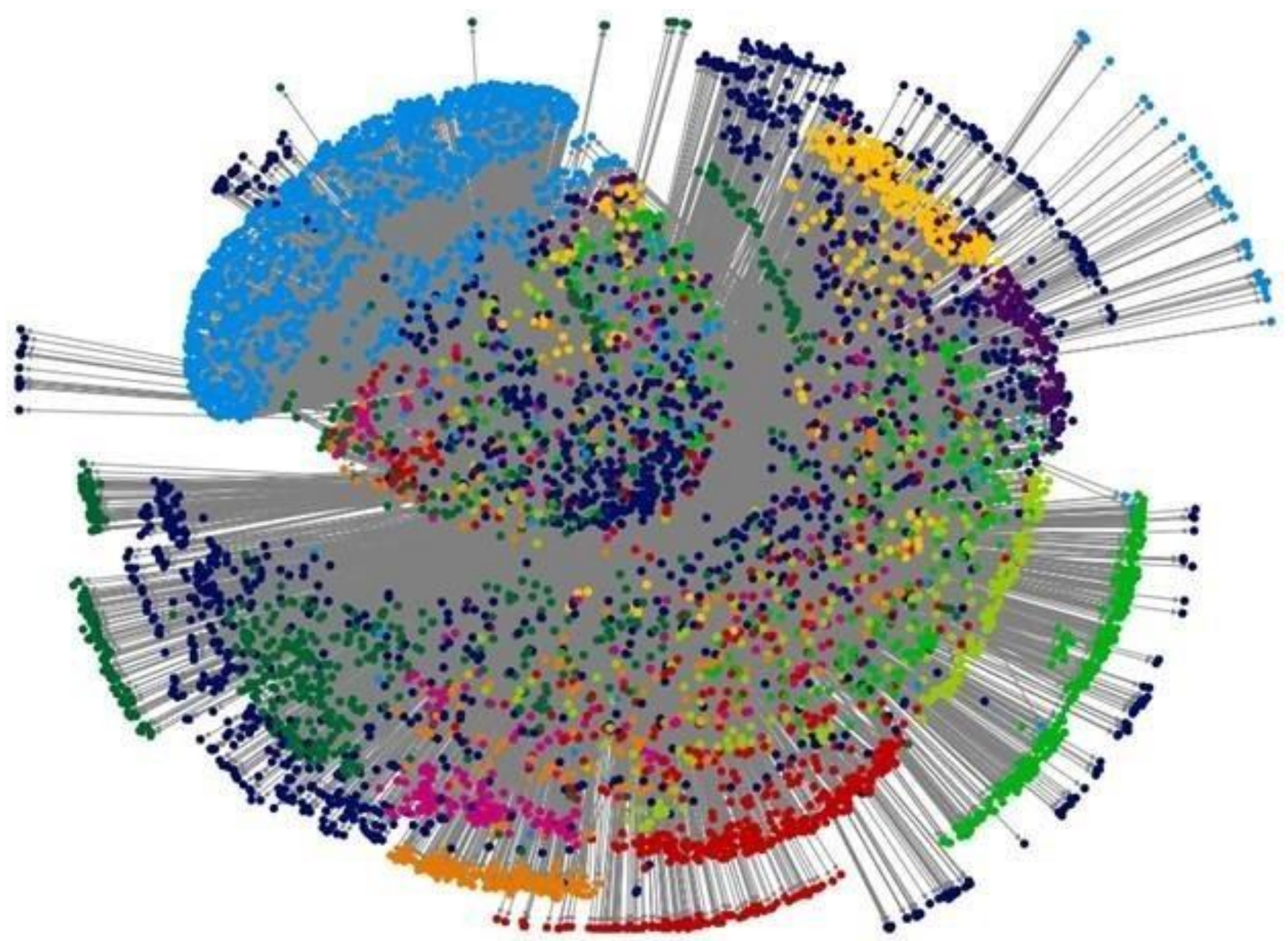

Figure 2 The educational administration journal citation network. The network consisted of 6,382 journals in 10 clusters (visualized in 10 different colors) according to the results of network cluster analysis by applying the Givan-Newman clustering algorithm (2002).

Accountability on January 1, 2008) appears not closely connected with the rest of seven clusters, because of the lack of a bridging tie (tie strength $\geq 50$ ) between the education evaluation journal cluster and others.

\section{Journal prominence.}

Given the purpose of the previous literature in educational administration (Campbell, 1979; Cherkowaski et al., 2011; Haas et al., 2007; Murphy et al., 2007; Richardson and McLeod, 2011) that had attempted to describe the rank order of journals in the field by citation frequency as well as survey responses, we turn next to replicating and extending this work by describing rank order of the journals. Moving beyond the sole dependence on citation frequency counts (Campbell, 1979; Haas et al., 2007; Murphy et al.,
2007; Richardson and McLeod, 2011) or on surveys of perceptions of journal prominence in the field (Campbell, 1979; Cherkowaski et al., 2011), here we rely on the results of social network analysis to provide evidence for the first time in the field on not only the rank order of the most prominent journals, but also the highly interdisciplinary journals because of the critical role of interdisciplinarity in knowledge creation (Zitt, 2005).

Table 2 provides a rank ordered list of the top 50 journals in the educational administration research literature according to Freeman indegree as an indicator of journal prominence (Table 2, left), and betweenness as an indicator of journal interdisciplinarity (Table 2, right). The results of 


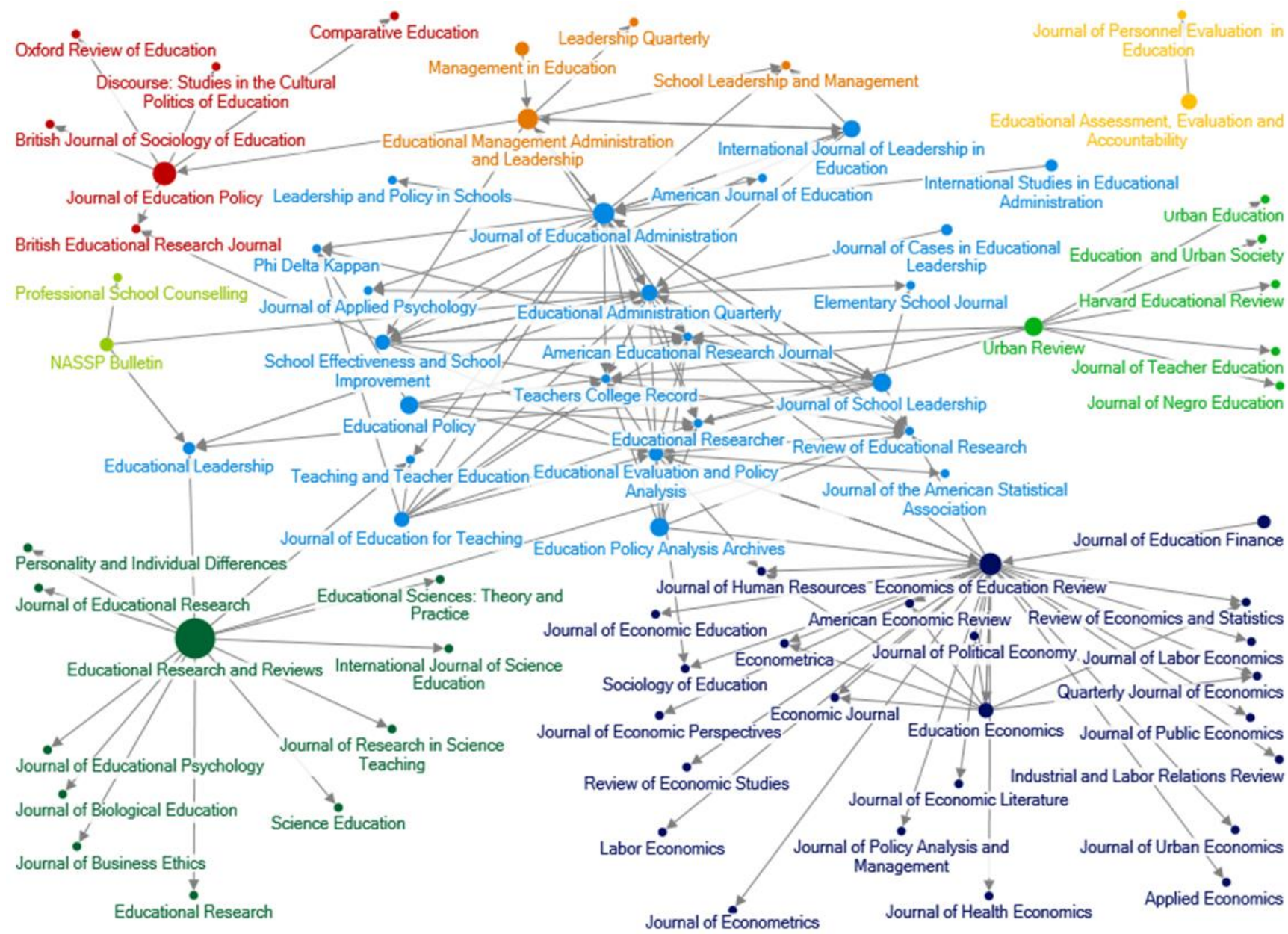

Figure $3 a$ The educational administration journal citation network (threshold: tie strength $\geq 50$ ). Vertex size represents betweenness centrality. A larger vertex indicates higher betweenness, suggesting a journal's higher interdisciplinarity. The tie arrows show where the citation ties originate and end. Eight colors represent eight clusters detected by performing the Givan-Newman clustering algorithm (2002).

Freeman indegree calculation also suggest many journals of sub-fields in education had high prominence in the educational administration journal citation network. These journals, according to the definition of Freeman indegree, were broadly and frequently cited by the 30 citing journals examined in the current study. This finding shows that the educational administration field relies on the knowledge from many education sub-fields: urban education (e.g., Education and Urban Society and Urban Education), educational sociology (e.g., Sociology of Education and British Journal of Sociology of Education), educational psychology (e.g., Journal of Educational Psychology), teacher education (e.g., Teaching and Teacher Education, Journal of
Teacher Education, and Journal of Education for Teaching), elementary school education (e.g., Elementary School Journal), and higher education (e.g., Journal of Higher Education).

In addition to education journals, the knowledge from other disciplines was disseminated to the educational administration field through dense citation ties. The high-indegree journals in Table 2 spanned from economics (e.g., American Economic Review, Review of Economics and Statistics, Journal of Public Economics, Econometrica, Journal of Economics), psychology (e.g., Journal of Applied Psychology and American Psychologist), and administration 


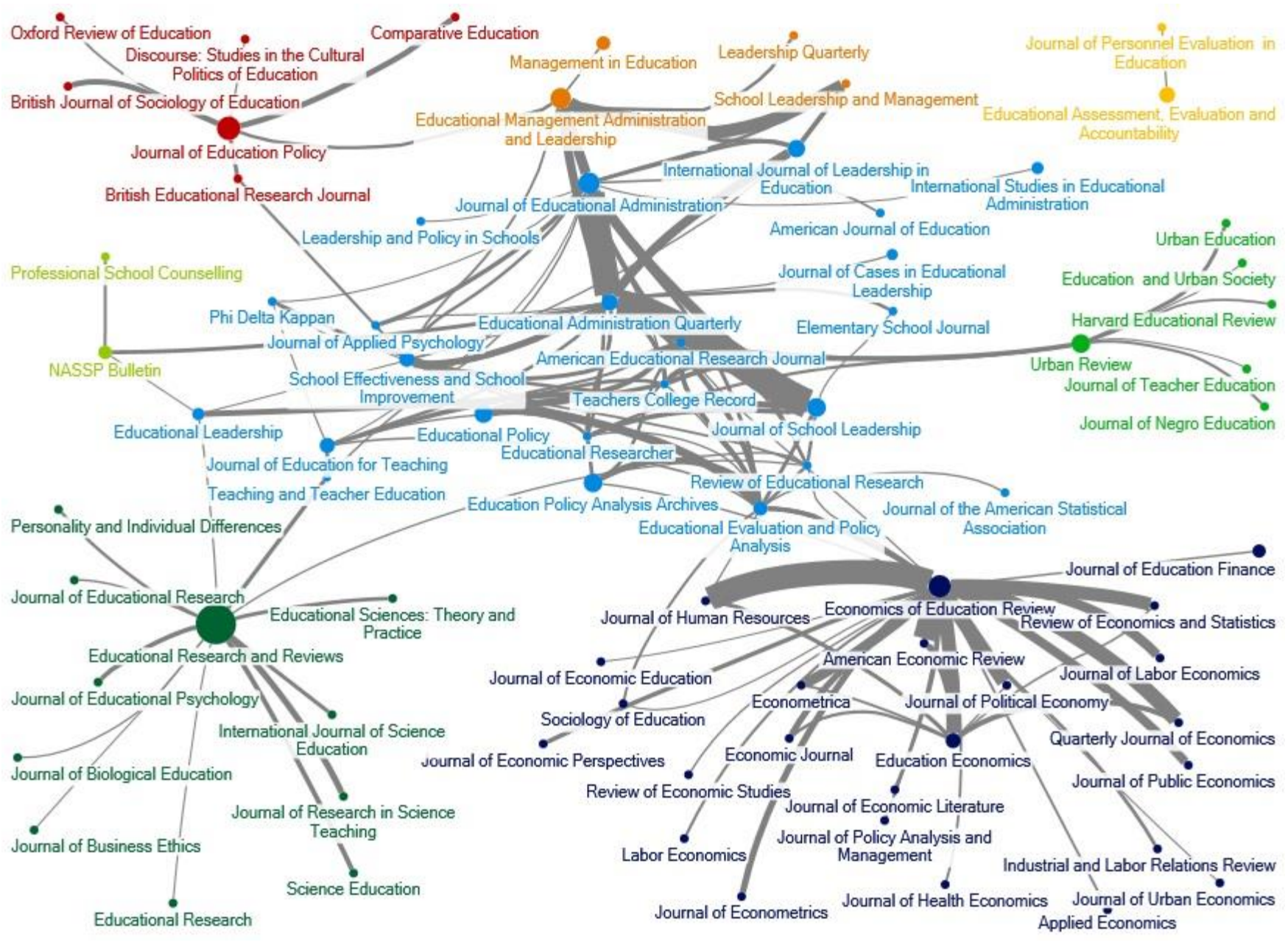

Figure $3 b$ To enhance the network readability, in this visualization the parallel citation ties were bundled together until they diverge close to different cited journals. The width of tie represent the strength of tie (threshold: tie strength $\geq 50$ ). The thicker the citation tie is, the more frequently the citation tie occurs between the journal pair of a citing journal and cited journal.

(Administrative Science Quarterly and Academy of Management Review).

\section{Journal interdisciplinarity.}

The result of journals' betweenness (Table 2, left) - a numeric measure of journal interdisciplinarity - are in congruence with the journal clusters in the network (Figure 3, a larger vertex size indicating higher betweenness). High-betweenness journals (e.g., Journal of Education Policy, Economics of Education Review, Journal of Educational Administration, and Urban Review) demonstrated their important bridging function in the educational administration knowledge exchange and dissemination. Specifically, Journal of Education Policy bridged between British journals in red color and international educational administration journals in orange color; Economics of Education Review bridged economic journals in dark blue and educational administration journals in light blue; Journal of Educational Administration bridged international educational administration journals in orange color and educational administration journals in light blue; Urban Review bridged urban education journals in light green and educational administration journals in light blue. Educational Research and Reviews (ERR), an open-access Turkish journal, has the highest betweenness, indicating ERR's broad interdisciplinary outreach. The arrows in the dark green cluster suggest ERR cited journals in education, science education, biological education, psychology, 
Table 2 High-centrality Journals

\begin{tabular}{|c|c|c|c|c|}
\hline Rank & Journal & $\begin{array}{l}\text { Freeman } \\
\text { indegree }\end{array}$ & Journal & Betweenness \\
\hline 1 & Educational Administration Quarterly & 1,778 & Educational Research and Reviews & $15,888,468$ \\
\hline 2 & American Educational Research Journal & 1,114 & Journal of Education Policy & $4,967,542$ \\
\hline 3 & Educational Evaluation and Policy Analysis & 1,037 & Economics of Education Review & $4,394,126$ \\
\hline 4 & Educational Researcher & 959 & Journal of Educational Administration & $3,974,259$ \\
\hline 5 & Teachers College Record & 933 & $\begin{array}{l}\text { Educational Management Administration } \\
\text { and Leadership }\end{array}$ & $3,616,424$ \\
\hline 6 & Review of Educational Research & 886 & Journal of School Leadership & $2,909,172$ \\
\hline 7 & Journal of Educational Administration & 843 & Urban Review & $2,879,861$ \\
\hline 8 & Educational Leadership & 723 & Education Policy Analysis and Archives & $2,867,306$ \\
\hline 9 & Phi Delta Kappan & 698 & Educational Policy & $2,635,750$ \\
\hline 10 & School Leadership and Management & 686 & $\begin{array}{l}\text { International Journal of Leadership in } \\
\text { Education }\end{array}$ & $2,415,428$ \\
\hline 11 & American Economic Review & 650 & Educational Administration Quarterly & $2,023,706$ \\
\hline 12 & Journal of Human Resources & 643 & $\begin{array}{l}\text { Journal for Critical Education Policy } \\
\text { Studies }\end{array}$ & $1,881,002$ \\
\hline 13 & Economics of Education Review & 607 & $\begin{array}{l}\text { Educational Assessment, Evaluation and } \\
\text { Accountability }\end{array}$ & $1,836,973$ \\
\hline 14 & Teaching and Teacher Education & 564 & $\begin{array}{l}\text { Canadian Journal of Educational } \\
\text { Administration and Policy }\end{array}$ & $1,790,935$ \\
\hline 15 & School Effectiveness and School Improvement & 495 & $\begin{array}{l}\text { School Effectiveness and School } \\
\text { Improvement }\end{array}$ & $1,653,729$ \\
\hline 16 & Sociology of Education & 479 & Journal of Education for Teaching & $1,631,202$ \\
\hline 17 & American Journal of Education & 458 & Education Economics & $1,567,360$ \\
\hline 18 & Quarterly Journal of Economics & 455 & $\begin{array}{l}\text { Educational Evaluation and Policy } \\
\text { Analysis }\end{array}$ & $1,336,334$ \\
\hline 19 & Elementary School Journal & 442 & $\begin{array}{l}\text { International Journal of Educational } \\
\text { Reform }\end{array}$ & $1,324,643$ \\
\hline 20 & $\begin{array}{l}\text { Educational Management Administration and } \\
\text { Leadership }\end{array}$ & 425 & Management in Education & $1,219,621$ \\
\hline
\end{tabular}


Table 2 continued

\begin{tabular}{|c|c|c|c|c|}
\hline Rank & Journal & $\begin{array}{l}\text { Freeman } \\
\text { indegree }\end{array}$ & Journal & Betweenness \\
\hline 21 & Review of Economics and Statistics & 414 & NASSP Bulletin & $1,129,087$ \\
\hline 22 & Journal of Educational Psychology & 412 & Journal of Education Finance & $1,048,592$ \\
\hline 23 & Educational Policy & 402 & Canadian Journal of Education & $1,038,326$ \\
\hline 24 & Peabody Journal of Education & 394 & Improving Schools & 816,012 \\
\hline 25 & Harvard Educational Review & 382 & Educational Leadership & 784,843 \\
\hline 26 & British Educational Research Journal & 364 & $\begin{array}{l}\text { International Studies in Educational } \\
\text { Administration }\end{array}$ & 736,993 \\
\hline 27 & Journal of Political Economy & 356 & Educational Planning & 717,757 \\
\hline 28 & Education and Urban Society & 346 & $\begin{array}{l}\text { Journal of Cases in Educational } \\
\text { Leadership }\end{array}$ & 537,268 \\
\hline 29 & Journal of Teacher Education & 331 & $\begin{array}{l}\text { Online Journal of Distance Learning } \\
\text { Administration }\end{array}$ & 518,039 \\
\hline 30 & Journal of School Leadership & 330 & $\begin{array}{l}\text { AASA: Journal of Scholarship and } \\
\text { Practice }\end{array}$ & 236,781 \\
\hline 31 & Journal of Education Policy & 321 & Educational Researcher & 16,135 \\
\hline 32 & Journal of Public Economics & 344 & Phi Delta Kappan & 16,135 \\
\hline 33 & Journal of Applied Psychology & 304 & Review of Educational Research & 16,135 \\
\hline 34 & Econometrica & 300 & Teachers College Record & 16,135 \\
\hline 35 & Journal of Education for Teaching & 288 & Journal of Educational Psychology & 16,135 \\
\hline 36 & Journal of Educational Research & 281 & Psychological Bulletin & 14,181 \\
\hline 37 & Leadership and Policy in Schools & 280 & Journal of Higher Education & 13,178 \\
\hline 38 & Journal of Higher Education & 279 & Higher Education & 12,812 \\
\hline 39 & NASSP Bulletin & 269 & Journal of Teacher Education & 12,804 \\
\hline 40 & $\begin{array}{l}\text { International Journal of Leadership in } \\
\text { Education }\end{array}$ & 263 & American Economic Review & 12,254 \\
\hline 41 & Journal of Labor Economics & 268 & Research in Higher Education & 10,282 \\
\hline 42 & Leadership Quarterly & 257 & American Educational Research Journal & 10,221 \\
\hline 43 & Administrative Science Quarterly & 250 & Peabody Journal of Education & 9,339 \\
\hline 44 & Urban Education & 259 & Educational Research & 8,849 \\
\hline
\end{tabular}


Table 2 continued

\begin{tabular}{cllll}
\hline Rank & Journal & $\begin{array}{l}\text { Freeman } \\
\text { indegree }\end{array}$ & Journal & Betweenness \\
\hline 45 & British Journal of Sociology of Education & 248 & Teacher Education Quarterly & 8,762 \\
46 & Theory Into Practice & 245 & Equity and Excellence in Education & 8,386 \\
47 & American Psychologist & 243 & $\begin{array}{l}\text { Educational Psychology Review } \\
\text { International Journal of Educational }\end{array}$ & 8,301 \\
48 & Academy of Management Review & 240 & Management & 7,848 \\
& & & Remedial and Special Education & 7,834 \\
49 & Child Development & 234 & Sociology of Education & 7,786 \\
50 & The Economic Journal & 233 & &
\end{tabular}


and business. Overall, high-betweenness journals helped bridge fields that do not often otherwise interact with each other-a task of critical importance for new knowledge creation.

\section{Non-journal Citations}

In addition to journals as the citation source, we found the percentage of non-journals as the source of citations accounts for approximately $54.71 \%$ of all 157,372 citations (see Table 1). Therefore, an exclusive focus on journals would leave out over half of the account. We thereby extracted the names of books and reports and then ranked them by citation frequency. Table 3 presents the most frequently cited books and reports in the 30 journals from 2009 to 2013, giving us important insights on these types of citations that make up $46.06 \%$ of the citations in the educational administration research literature. First, the Equality of Education Opportunity (Coleman) Study published in 1966 was the most cited report, delineating the persistent pursuit of education equality over the last half a century. Second, 12 of 50 most cited books were on qualitative research methodology (e.g., Qualitative Data Analysis: An Expanded Sourcebook and Basics of Qualitative Research: Grounded Theory Procedures and Techniques), in sharp contrast to only four books on quantitative research methods (e.g., Hierarchical Linear Models: Applications and Data Analysis and Statistical Power Analysis for the Behavior Sciences). Third, Michael Fullan is the author having the most books cited in the educational administration research literature over from 2009 to 2013. His three books-The New Meaning of Education Change (1991, 2001, 2007), Leading in a Culture of Change (2001, 2007), and Change Forces: Probing the Depths of Educational Reform (1993, 1999, 2003)—were cited 193 times in total. This finding underscores not only Fullan's undeniable influence on the field, but also manifests that educational change has been placed at the nexus of educational administration. Finally, social justice is a salient theme in the books in Table 3, as evidenced by the most cited books of Keeping Track: How Schools Structure Inequality by Oakes (1985, 2005), Educating the Right Way: Markets, Standards, God, and Inequality by Apple (2001, 2006), Discipline and Punish: The Birth of the Prison by Foucault (1975, 1977, 1979, 1995), Education Reform: A Critical and Post-Structural Approach by Ball (1994), and Other People's Children: Cultural Conflict in the Classroom by Delpit (1995, 2006). These books provided the knowledge base for social justice, guiding both scholarly inquiry and leadership practice. In sum, all the aforementioned results provide the first opportunity to view the evidence across the field of educational administration as to the foci, lenses, theories, and main conceptualizations that the field uses as its central touchstones in its work to understand the theory, research, and practice of educational leadership.

\section{DISCUSSION}

The purpose of this study is to uncover how knowledge is exchanged and disseminated in the educational administration research literature through the journal citation network. By analyzing how knowledge is exchanged and disseminated in the educational administration research literature through the citation network structure, we generated useful insights regarding the educational administration's interdisciplinary nature, as well as the disciplines involved in the educational administration research literature.

\section{Educational Administration as a Porous Field}

Our findings suggest that educational administration is a porous field that is open and outward-oriented in seeking new information, theories, and knowledge to aid in understanding the field. First, the broadly and frequently cited journals (i.e., high-indegree journals), along with the eight journal clusters detected by network cluster analysis, delineate that educational administration journals not only rely upon the core literature, as evidenced by the dense citation ties within the light blue cluster of primarily educational administration and education journals, but also intimately interacts with urban education, economics, sociology, psychology, as well as international studies. More telling, our findings indicate the evolving, dynamic interdisciplinary boundaries of the educational administration field. Unlike education and sociology as the only two disciplines substantially contributing to the educational administration field in 1960s (Haller, 1968), our findings uncovered that the field has extended its interdisciplinary outreach to the sub-fields of education (e.g., urban education, teacher education, educational sociology, educational psychology, elementary education, and higher education), human resources, economics, and administration. 
Table 3 Top-cited Books/Reports in the Educational Administration Field from 2009 to 2013

\begin{tabular}{|c|c|c|c|c|c|}
\hline Rank & First author & Book/report name & Frequency & Year & Publisher \\
\hline 1 & Miles, M.B. & Qualitative Data Analysis: An Expanded Sourcebook & 135 & 1994 & Sage \\
\hline 2 & Strauss, A. & $\begin{array}{l}\text { Basics of Qualitative Research: Grounded Theory Procedures } \\
\text { and Techniques }\end{array}$ & 109 & 1990 & Sage \\
\hline 3 & Patton, M.Q. & Qualitative Research and Evaluation Methods & 108 & 2002 & Sage \\
\hline 4 & Fullan, M. & The New Meaning of Educational Change & 98 & $\begin{array}{l}1991, \\
2001, \\
2007,\end{array}$ & $\begin{array}{l}\text { Teachers College } \\
\text { Press }\end{array}$ \\
\hline 5 & Freire, $\mathrm{P}$. & Pedagogy of the Oppressed & 94 & $\begin{array}{l}1970, \\
1982, \\
1989, \\
1994, \\
1996, \\
1999, \\
1999, \\
2000, \\
2002, \\
2006\end{array}$ & $\begin{array}{l}\text { Bloomsbury } \\
\text { Academic }\end{array}$ \\
\hline 6 & Spillane, J. & Distributed Leadership & 83 & 2006 & Jossey-Bass \\
\hline 7 & Bryk, A. & Trust in Schools: A Core Resource for Improvement & 83 & $\begin{array}{l}2001 \\
2004\end{array}$ & $\begin{array}{l}\text { Russell Sage } \\
\text { Foundation } \\
\text { Publications }\end{array}$ \\
\hline 8 & Denzin, N. & The Sage Handbook of Qualitative Research & 82 & 2005 & Sage \\
\hline 9 & $\begin{array}{l}\text { Raudenbush, } \\
\text { S.W. }\end{array}$ & $\begin{array}{l}\text { Hierarchical Linear Models: Applications and Data Analysis } \\
\text { Methods }\end{array}$ & 75 & 2002 & Sage \\
\hline 10 & Glaser, B. & $\begin{array}{l}\text { The Discovery of Grounded Theory: Strategic for Qualitative } \\
\text { Research }\end{array}$ & 74 & 1967 & Aldine Transaction \\
\hline 11 & $\begin{array}{l}\text { Leithwood, } \\
\text { K. }\end{array}$ & How Leadership Influences Student Learning & 72 & 2004 & $\begin{array}{l}\text { The Wallace } \\
\text { Foundation }\end{array}$ \\
\hline 12 & Lincoln, Y.S. & Naturalistic Inquiry & 71 & 1985 & Sage \\
\hline
\end{tabular}


Table 3 continued

\begin{tabular}{|c|c|c|c|c|c|}
\hline Rank & First author & Book/report name & Frequency & Year & Publisher \\
\hline 13 & $\begin{array}{l}\text { Creswell, } \\
\text { J.W. }\end{array}$ & $\begin{array}{l}\text { Qualitative Inquiry and Research Design: Choosing Among } \\
\text { Five Approaches }\end{array}$ & 66 & 1998 & Sage \\
\hline 14 & Lortie, D.C. & Schoolteacher: A Sociological Study & 60 & $\begin{array}{l}1975 \\
1998 \\
2002\end{array}$ & $\begin{array}{l}\text { University of } \\
\text { Chicago Press }\end{array}$ \\
\hline 15 & $\begin{array}{l}\text { Merriam, } \\
\text { S.B. }\end{array}$ & $\begin{array}{l}\text { Qualitative Research and Case Study Applications in } \\
\text { Education }\end{array}$ & 59 & $\begin{array}{l}1998 \\
2001\end{array}$ & Jossey-Bass \\
\hline 16 & Yin, R.K. & Case Study Research: Design And Methods & 57 & $\begin{array}{l}1994, \\
2013\end{array}$ & Sage \\
\hline 17 & Fullan, M. & Leading in a Culture of Change & 56 & $\begin{array}{l}2001 \\
2007\end{array}$ & Jossey-Bass \\
\hline 18 & $\begin{array}{l}\text { Coleman, } \\
\text { J.S. }\end{array}$ & Equality of Educational Opportunity (Coleman) Study & 53 & 1966 & $\begin{array}{l}\text { Inter-university } \\
\text { Consortium for } \\
\text { Political and Social } \\
\text { Research }\end{array}$ \\
\hline 19 & Bogdan, R. & $\begin{array}{l}\text { Qualitative Research For Education: An Introduction to } \\
\text { Theories and Methods }\end{array}$ & 51 & $\begin{array}{l}1982, \\
1992, \\
1998, \\
2003, \\
2007\end{array}$ & Pearson \\
\hline 20 & Tyack, D. & Tinkering Toward Utopia: A Century of Public School Reform & 48 & $\begin{array}{l}1995 \\
2000\end{array}$ & $\begin{array}{l}\text { Harvard University } \\
\text { Press }\end{array}$ \\
\hline 21 & $\begin{array}{l}\text { National } \\
\text { Commission } \\
\text { on } \\
\text { Excellence in } \\
\text { Education }\end{array}$ & A Nation at Risk: The Imperative for Educational Reform & 46 & 1983 & N/A \\
\hline 22 & Oakes, J. & Keeping Track: How Schools Structure Inequality & 46 & $\begin{array}{l}1985 \\
2005\end{array}$ & $\begin{array}{l}\text { Yale University } \\
\text { Press }\end{array}$ \\
\hline
\end{tabular}


Table 3 continued

\begin{tabular}{|c|c|c|c|c|c|}
\hline Rank & First author & Book/report name & Frequency & Year & Publisher \\
\hline 23 & Cohen, L. & Research Methods in Education & 46 & $\begin{array}{l}1989, \\
1994, \\
2000, \\
2001, \\
2007\end{array}$ & Routledge \\
\hline 24 & Wenger, E. & Communities of Practice: Learning, Meaning and Identity & 45 & $\begin{array}{l}1998 \\
2000\end{array}$ & $\begin{array}{l}\text { Cambridge } \\
\text { University Press }\end{array}$ \\
\hline 25 & Hoy, W. & Educational Administration: Theory, Research, and Practice & 44 & $\begin{array}{l}2001, \\
2005\end{array}$ & $\begin{array}{l}\text { McGraw-Hill } \\
\text { Humanities/Social } \\
\text { Sciences/Languages }\end{array}$ \\
\hline 26 & Murphy, J. & Handbook of Research on Educational Administration & 43 & 1999 & Jossey-Bass \\
\hline 27 & $\begin{array}{l}\text { National } \\
\text { Center for } \\
\text { Education } \\
\text { Statistics }\end{array}$ & The Condition of Education & 42 & $\begin{array}{l}\text { from } \\
2000 \\
\text { to } \\
2010\end{array}$ & $\begin{array}{l}\text { Department of } \\
\text { Education }\end{array}$ \\
\hline 28 & $\begin{array}{l}\text { Whittrock, } \\
\text { M.C. }\end{array}$ & Handbook of Research on Teaching & 40 & 1986 & Macmillan \\
\hline 29 & Schein, E.H. & Organizational Culture and Leadership & 40 & $\begin{array}{l}1985 \\
1992 \\
2001 \\
2004\end{array}$ & Jossey-Bass \\
\hline 30 & Fullan, M. & Change Forces: Probing the Depths of Educational Reform & 39 & $\begin{array}{l}1993 \\
1999, \\
2003\end{array}$ & Routledge \\
\hline 31 & $\begin{array}{l}\text { Hargreaves, } \\
\text { A. }\end{array}$ & Sustainable Leadership & 38 & 2006 & Jossey-Bass \\
\hline 32 & Ball, S.J. & $\begin{array}{l}\text { The Education Debate: Policy and Politics in The } 21^{\text {st }} \\
\text { Century }\end{array}$ & 38 & 2008 & Policy Press \\
\hline 33 & $\begin{array}{l}\text { Hargreaves, } \\
\text { A. }\end{array}$ & $\begin{array}{l}\text { Changing Teachers, Changing Times: Teachers' Work and } \\
\text { Culture in the Postmodern Age }\end{array}$ & 37 & 1994 & $\begin{array}{l}\text { Teachers College } \\
\text { Press }\end{array}$ \\
\hline
\end{tabular}


Table 3 continued

\begin{tabular}{|c|c|c|c|c|c|}
\hline Rank & First author & Book/report name & Frequency & Year & Publisher \\
\hline 34 & Elmore, R.F. & $\begin{array}{l}\text { School Reform From the Inside Out: Policy, Practice, and } \\
\text { Performance }\end{array}$ & 37 & 2004 & $\begin{array}{l}\text { Harvard Education } \\
\text { Press }\end{array}$ \\
\hline 35 & Cohen, J. & Statistical Power Analysis for the Behavioral Sciences & 37 & 1988 & Routledge \\
\hline 36 & Apple, M.W. & $\begin{array}{l}\text { Educating the Right Way: Markets, Standards, God, and } \\
\text { Inequality }\end{array}$ & 36 & $\begin{array}{l}2001, \\
2006\end{array}$ & Routledge \\
\hline 37 & Foucault, M. & Discipline and Punish: The Birth of the Prison & 35 & $\begin{array}{l}1975, \\
1977, \\
1979, \\
1995\end{array}$ & Vintage Books \\
\hline 38 & Bryk, A. & Organizing Schools for Improvement: Lessons From Chicago & 35 & 2010 & $\begin{array}{l}\text { University Of } \\
\text { Chicago Press }\end{array}$ \\
\hline 39 & Marshall, C. & Designing Qualitative Research & 34 & $\begin{array}{l}1995, \\
1999, \\
2006, \\
2011\end{array}$ & Sage \\
\hline 40 & Fraenkel, J. & How to Design and Evaluate Research in Education & 34 & $\begin{array}{l}1993, \\
2000, \\
2003, \\
2006, \\
2008\end{array}$ & $\begin{array}{l}\text { McGraw-Hill } \\
\text { Humanities/Social } \\
\text { Sciences/Languages }\end{array}$ \\
\hline 41 & Hattie, J. & $\begin{array}{l}\text { Visible Learning: A Synthesis of Over } 800 \text { Meta-Analyses } \\
\text { Relating to Achievement }\end{array}$ & 34 & 2009 & Routledge \\
\hline 42 & Strauss, A. & $\begin{array}{l}\text { Basics of Qualitative Research: Grounded Theory Procedures } \\
\text { and Techniques }\end{array}$ & 33 & $\begin{array}{l}1990, \\
1998, \\
2008\end{array}$ & Sage \\
\hline 43 & Elmore, R.F. & Building a New Structure for School Leadership & 32 & 2000 & $\begin{array}{l}\text { The Albert Shanker } \\
\text { Institute }\end{array}$ \\
\hline 44 & Stake, R.E. & The Art of Case Study Research & 31 & 1995 & Sage \\
\hline 45 & Rizvi, F. & Globalizing Education Policy & 30 & 2010 & Routledge \\
\hline
\end{tabular}


Table 3 continued

\begin{tabular}{|c|c|c|c|c|c|}
\hline Rank & First author & Book/report name & Frequency & Year & Publisher \\
\hline 46 & Ravitch, D. & $\begin{array}{l}\text { The Death and Life of the Great American School System: } \\
\text { How Testing and Choice Are Undermining Education }\end{array}$ & 30 & 2011 & Basic Books \\
\hline 47 & $\begin{array}{l}\text { Leithwood, } \\
\text { K. }\end{array}$ & Changing Leadership for Changing Times & 29 & $\begin{array}{l}1999, \\
2002\end{array}$ & $\begin{array}{l}\text { Open University } \\
\text { Press }\end{array}$ \\
\hline 48 & Lave, $\mathrm{J}$. & Situated Learning: Legitimate Peripheral Participation & 29 & 1991 & $\begin{array}{l}\text { Cambridge } \\
\text { University Press }\end{array}$ \\
\hline 49 & Ball, S.J. & Education Reform: A Critical and Post-Structural Approach & 28 & 1994 & $\begin{array}{l}\text { Open University } \\
\text { Press }\end{array}$ \\
\hline 50 & Delpit, L. & Other People's Children: Cultural Conflict in The Classroom & 28 & $\begin{array}{l}1995, \\
2006\end{array}$ & The New Press \\
\hline
\end{tabular}


Second, non-journal citations are the majority of sources of citations in the educational administration research literature. Our results indicate for the first time in the literature that the percentage of non-journal sources was higher than journal sources in the educational administration research. As a result, in examining the educational administration field, an exclusive focus on journal-to-journal citations provides an incomplete picture as the majority (54.71\%) of citations in the research literature rely on non-journal sources. This finding could be interpreted in two very different ways. The positive interpretation is that the educational administration field is open to outside ideas and alternative forms of publication. This might be the field's unique scholarly communication system that is not limited to journals but rather includes a variety of publication media, as noted by Haller (1968). Another interpretation extends the discourse of whether there is a balance between the openness to new ideas and the rigorous scrutiny of all ideas in the educational administration field. The advancement of science entails a balance between being open to new ideas and scrutinizing all ideas (Sagan, 1997). The diverse citation sources in the educational administration research literature suggest the field's openness to new ideas. To stay relevant, it appears that the educational administration field is adaptive, dynamic, and constantly scanning the culture and the larger literature beyond purely peer reviewed journals for information as to what may be important for understanding how schools operate. This is important, especially in the U.S. context, since the purpose of schooling is far from agreed upon (Labaree, 1997). Thus, there appears to be a strong sense of purpose to the educational administration research of weaving, incorporating, and integrating the current conversations in the greater culture into a rich tapestry of research on educational administration. However, only less than half (45.29\%) of the citations in the recent literature across the 30 educational administration journals are subject to peer review, a process that represents a useful and meaningful check on the veracity, validity, and reliability of the research findings (Bornmann, 2011). In education research, Makel and Plucker (2014) cautioned against a value of novelty over truth in education sciences after noting that only $0.13 \%$ of education articles in the top 100 education journals ranked by 5-year impact factor were replications - the repetition of previous studies in order to "corroborate or disconfirm the previous results" (p. 305). Our findings on the diverse sources of citations in the educational administration research literature, coupled with Makel and Plucker's (2014) finding on the dearth of replication studies, draw attention to the critical balance of the openness to new ideas and rigorous scrutiny of all ideas. This balance is of particular importance in the context of using reliable and trustworthy research findings to shape educational policy and leadership practice (Riehl and Firestone, 2005; Schneider et al., 2007; Shavelson and Towne 2002).

\section{Social Network Analysis as an Alternative and Useful Tool for Journal Studies}

Our study is the first journal citation network analysis of 30 citing journals in the educational administration field. The distinctive feature of this study from prior journal studies in this domain is that we employed social network analysis to the journal citation analysis in educational administration. We not only looked at how frequently a given journal is cited by others, but also how other journals interact with one another through citation patterns. The findings of journal interdisciplinarity and network cluster analysis add to the understanding of how certain journals function as boundary spanners by their structural position between different clusters in the educational administration journal citation network. For example, Urban Review, on the one hand, cites the journals in the urban education journal cluster in light green color (e.g., Journal of Negro Education, Urban Education, and Education and Urban Society); on the other hand, it cites education journals (e.g., American Educational Research Journal, Teachers College Record, and Educational Researcher). These citation patterns enable Urban Review to function as a bridge between the two journal clusters, playing a role of knowledge broker in education and urban education. Another example of bridging journals is the Journal of Educational Administration (JEA) - a journal that explicitly states on its website that $J E A$ "presents international knowledge" (JEA, n.d., para. 1). In Figure 3 , we found that $J E A$, located in the core educational administration journal cluster, has dense citation ties to the international educational administration journals, such as Educational Management Administration \& Leadership, School Leadership \& Management, International Journal of Leadership in Education, and International Studies in Educational Administration. These citation ties between the JEA and international journals truly 
manifest the JEA's international scope stated by its former editor Thomas (2012), the JEA's five decades' legacies as denoted by Oplatka (2012), as well as the $J E A$ 's role in bridging the educational administration research in the United States and global context. Additionally, the results of social network analysis postulate a need for additional journals that serve the knowledge broker roles. Of particular interest, the upper right "yellow" cluster in Figure 3 that contains education assessment, evaluation, and human resources journals is not connected to the larger network of educational administration at the tie strength greater than or equal to 50 . We posit that this finding is significant given the rising recent demands on educational leaders on the issues of accountability, assessment (Barnett et al., 2013; Firestone and Shipps, 2005; Gonzalez and Firestone, 2013; Leithwood, 2013) and human resources in policy and practice (Bowers, 2008; Firestone et al., 2005; Leithwood et al., 2008). We argue that our analysis provides strong evidence for the need of a bridging tie in the journal citation network to facilitate knowledge sharing between these important domains.

What is most exciting about this study is not merely the colorful network visualization that helps discern the journal citation patterns against the backdrop of 157,372 citations, but the way that social network analysis, as an alternative research tool, adds the theoretical and analytical base to a dynamic research agenda for the educational administration field. In the current study, the utilization of social network analysis allowed us to move beyond citation frequency counts and focused on the citation ties in a socially constructed journal citation network in which knowledge is shared from one journal to another, visualizing a highly contextualized map of the field as a means to present the empirical results. By doing so, we overcame the constraints of previous studies on journal influence by proposing Freeman indgree as a journal prominence measure and betweenness as a journal interdisciplinarity measure. Thus, social network analysis lays the foundation for future research on educational administration journals. As an example, our findings suggest that the educational administration research journals serve an important brokering role between urban education, psychometrics and the education sciences, international education, and economics of education. Given the strong ties within the central light blue educational administration cluster in Figure 3, we posit that educational administration provides an integral role in knowledge generation and dissemination in the larger educational research field.

\section{Limitations and Directions for Future Inquiry}

As the first study of applying social network analysis to analyze the literature in educational administration, we recognize that our analyses were limited in the following ways. First, the journal citation network in the current study was bounded by the scope of 30 citing journals. While we selected these 30 journals as the citing journals based on the journals examined in the previous literature (Campbell, 1979; Cherkowski et al., 2011; Hass et al., 2007; Murphy et al., 2007; Richardson and McLeod, 2009), we recognize that these 30 citing journals were not an exhaustive summary of all educational administration journals. Future studies could rely on our results, and compile a more comprehensive list of educational administration journals, determined not by a pre-conceived list, but strictly by all journals pertinent to educational administration as evidenced by the citation network data.

Second, another limitation of this study concerns the one-time snapshot of the educational administration research literature. Although this study is by far the largest-scale study of educational administration journals, as we analyzed a total of 157,372 citations in 5,359 articles in 30 educational administration journals, we only uncovered the citation patterns from 2009 to 2013, given the limits imposed by journal accessibility. Therefore, we did not track the growth and development of the educational administration field in terms of the emergence of new disciplines that have been engaged in the educational administration research literature. Further, as open-access journals have been making their way as publishing outlets (Moed, 2007; Zhao, 2014), we recommend that future studies examine whether open access affect a journal's prominence and interdisciplinarity.

Third, the current study only focused on one side of the coin-how other disciplines contributed to educational administration by looking at the citation ties from educational administration journals to the journals in other disciplines. As educational administration evolves as a field, it would be intriguing to take a reflective look at the other side of the coin - how much educational administration has contributed to other disciplines, as originally suggested 
by Campbell (1979). To what extent is educational administration a reference discipline? A reference discipline needs to provide a conceptual foundation for another field (Keen, 1980), or at least is extensively cited by other fields (Wade et al., 2006). The field of educational administration has grown and evolved since its inception in 1960s, we thus encourage future studies to examine how much of a contribution the educational administration field has made to other fields.

\section{Conclusion}

This study presented abundant evidence that educational administration is a porous, open, and outward-oriented field. Truly, this article itself exhibits the interdisciplinary nature of research in educational administration by using social network theory in sociology as the theoretical underpinnings of the current study. Moreover, our findings pose a question on how to bridge the gap between the research and practice in educational administration. In an applied field as such as educational administration, it is of great importance to bring the work of practitioners and scholars together, as advocated by Willower and Culbertson (1964). An insight into the mechanism of knowledge exchange and dissemination between the educational administration research literature and practitioner literature not only advances our understanding that educational administration is a porous field, but also guides and informs the translation of research literature into the professional practice of leading schools.

\section{Acknowledgements:}

The authors would like to gratefully thank Sreekar Reddy Anugu for his help with the scripts used in the Java programming for this study.

\section{Suggested Citation:}

Wang, Y., Bowers, A.J. (2016) Mapping the Field of Educational Administration Research: A Journal Citation Network Analysis of the Discipline. Journal of Educational Administration, 54(3), p.242-269. http://dx.doi.org/10.1108/JEA-02-2015-0013

\section{REFERENCES:}

$\mathrm{Au}, \mathrm{W}$. and Ferrare, J.J. (2014), "Sponsors of policy: A network analysis of wealthy elites, their affiliated philanthropies, and charter school reform in Washington State", Teachers College Record, Vol.116, 080306.

Wang \& Bowers (2016)
Barnett, B.G., Shoho, A.R. and Bowers, A.J. (2013), "Introduction to Volume 4 of the International Research on School Leadership Book Series", in Barnett, B.G., Shoho, A.R. and Bowers, A.J. (Eds.), School and District Leadership in an Era of Accountability, Information Age Publishing Inc., Charlotte, NC, pp. 1-12.

Barnett, G., Huh, C., Kim, Y. and Park, H.W. (2011), "Citation among communication journals and other disciplines: A network analysis", Scientometrics, Vol. 88, pp. 449-469.

Bates, R.J. (1980), "Educational administration, the sociology of science, and the management of knowledge", Educational Administration Quarterly, Vol. 16 No. 2, pp. 1-20.

Bensman, S.J. (2001), "Bradford's law and fuzzy sets: Statistical implications for library analyses", IFLA Journal, Vol. 27, pp. 238-246.

Bowers, A.J. (2008), "Promoting Excellence: Good to great, NYC's district 2, and the case of a high performing school district", Leadership and Policy in Schools, Vol. 7 No. 2, pp. 154-177.

Borgatti, S.P. and Everett, M.G. (1992), "Notions of position in social network analysis", Sociology Methodology, Vol. 22, pp. 1-35.

Borgatti, S.P., Everett, M.G. and Freeman, L.C. (2002), UCINET 6 for Windows: Software for Social Network Analysis, Analytic Technologies, Harvard, MA.

Borgatti, S.P. and Foster, P. (2003), "The network paradigm in organizational research: A review and typology", Journal of Management, Vol. 29 No. 6, pp. 991-1013.

Borgatti, S.P. and Ofem, B. (2010), "Overview: social network theory and analysis", in Daly A.J. (Ed.), Social Network Theory and Educational Change, Harvard Education Press, Cambridge, MA, pp. 1729.

Borgman, C.L. (1989), "Bibliometrics and scholarly communication: Editor's introduction", Communication Research, Vo. 16, pp. 583-599.

Bornmann, L. (2011), "Scientific peer review", Annual Review of Information Science and Technology, Vol. 45 No. 1, pp. 197-245.

Brandes, U. (2001), "A faster algorithm for betweenness centrality", Journal of Mathematical Sociology, Vol. 25 No. 2, pp. 163-177.

Brughmans, T. (2013), "Networks of networks: A citation network analysis of the adoption, use, and adaptation of formal network techniques in 
archeology", Literacy and Linguistic Computing, Vol. 28 No. 4, pp. 538-562.

Burt, R.S. (1976), "Positions in networks", Social Forces, Vol. 55 No. 1, pp. 93-122.

Burt, R.S. (1980), "Innovation as a structural interest: Rethinking the impact of network position on innovation adoption", Social Networks, Vol. 2 No. 4, pp. 327-355.

Burt, R.S. (1982), Toward a structural theory of action, Academic Press, New York, NY.

Bush, T. (1999), "Crisis or crossroads? The discipline of educational management in the late

1990s", Educational Management and Administration, Vol. 27 No. 3, pp. 239-52.

Campbell, R.F. (1979), "Fifteenth anniversary perspective: A critique of the Educational Administration Quarterly", Educational Administration Quarterly, Vol. 15 No. 3, pp. 1-19.

Campbell, R.F. (1981), "The professorship in educational administration: a personal view",

Educational Administration Quarterly, Vol. 17 No. 1, pp. 1-24.

Chakraborty, T., Ganguly, N. and Mukherjee, A. (2014), "Rising popularity of interdisciplinary research-An analysis of citation networks", in 2014 proceedings of the Sixth International Conference on Communication Systems and Networks in India. doi: 10.1109/COMSNETS.2014.6734940

Cherkowski, S., Currie, R. and Hilton, S. (2011), "Who should rank our journals... and based on what?", Journal of Educational Administration, Vol. 50 No. 2, pp. 206-230.

Culbertson, J.A. (1981), "Antecedents of the theory movement", Educational Administration

Quarterly, Vol. 17 No. 1, pp. 25-47.

Daly, A.J. (2010), Social Network Theory and Educational Change. Harvard Education Press, Cambridge, MA.

Davis, G.F. (2014), "Editorial essay: Why do we still have journals?", Administrative Science Quarterly, Vol. 59 No. 2, pp. 193-201.

Degenne, A. and Forse, M. (1999), Introducing Social Networks. Sage Publications, London, UK.

Erickson, D.A. (1979), "Research on educational administration: The state of the art", Educational Researcher, Vol. 8 No. 3, pp. 9-14.

Evers, C.W. and Lakomski, G. (2012), "Science, systems, and theoretical alternatives in educational administration: The road less travelled", Journal of Educational Administration, Vol. 50 No. 1, pp. 57-75.

Freeman, L.C. (1977), “A set of measures of centrality based on Betweenness", Sociometry, Vol 40, pp. $35-41$.

Freeman, L.C. (1979), "Centrality in social networks: Conceptual Clarification", Social Networks, Vol. 1, pp. 215-239.

Firestone, W.A., Mangin, M. M., Martinez, M. C. and Polovsky, T. (2005), "Leading coherent professional development: A comparison of three districts", Educational Administration Quarterly, Vol. 41 No. 3, pp. 413-448.

Firestone, W.A. and Shipps, D. (2005), "How do leaders interpret conflicting accountabilities to improve student learning?", in Firestone W.A. and Riehl C. (Eds.), A New Agenda for Research in Educational Leadership, Teachers College Press, New York, NY, pp. 81-100.

Fitz, J. (1999), "Reflections on the field of educational management studies", Educational

Management and Administration, Vol. 27 No. 3, pp. 313-21.

Givan, M. and Newman, M.E.J. (2002), "Community structure in social and biological networks", Proceedings of the National Academy of Sciences of the United States of America, Vol. 99 No. 12, pp. 7821-7826.

Glatter, R. (1987), "Towards and agenda for education management", Educational Management

and Administration, Vol. 15, pp. 5-12.

Gonzalez, R.A. and Firestone, W.A. (2013), "Educational tug-of-war: internal and external accountability of principals in varied contexts", Journal of Educational Administration, Vol. 51 No. 3, pp. 383-406.

Griffiths, D.E. (1997), "The case for theoretical pluralism", Educational Management,

Administration and Leadership, Vol. 25 No. 4, pp. 371-80.

Haas, E., Wilson, G.Y., Cobb, C.D., Hyle, A.E., Jordan, K. and Kearney, K.S. (2007),

"Assessing influence on the field: An analysis of citations to Educational Administration

Quarterly, 1979-2003", Educational Administration Quarterly, Vol. 43 No. 4, pp. 494-513.

Haller, E. J. (1968), "The interdisciplinary ideology in educational administration: Some preliminary notes on the sociology of knowledge", Educational Administration Quarterly, Vol. 4 No. 2, pp. 61-77. 
Hallinger. P. and Chen, J. (2015), "Review of research on educational leadership and management in Asia: A comparative analysis of research topics and methods, 1995-2012", Educational Management Administration \& Leadership, Vol. 43 No. 1, pp. 5-27.

Heck, R.H. and Hallinger, P. (2005), "The study of educational leadership and management", Educational Management Administration \& Leadership, Vol. 33 No. 2, 229-244.

Hodgkinson, C. (1981), "A new taxonomy of administrative process", Journal of Educational

Administration, Vol. 19 No. 2, pp. 141-52.

Journal of Educational Administration. (n.d.), "Aims and scope", available at: http://emeraldgrouppublishing.com/products/journ als/journals.htm?id=jea (accessed 8 December 2015)

Keen, P.G. (1980), "MIS research: Reference discipline and a cumulative tradition", in Proceedings from the First International Conference on Information Systems in Philadelphia, PA, 1980, ICIS, pp. 9-18.

Kilduff, M. and Krackhardt, D. (2008), Interpersonal Networks in Organizations: Cognition, Personality, Dynamics, and Culture: Structural Analysis in the Social Sciences, Cambridge University Press, Cambridge, UK.

Labaree, D.F. (1997), "Public goods, private goods: The American struggle over educational goals", American Educational Research Journal, Vol. 34 No. 1, pp. 39-81.

Leithwood, K. (2013), "Concluding synthesis and commentary", in Barnett, B.G., Shoho, A.R. and Bowers, A.J. (Eds.), School And District Leadership in an Era of Accountability, Information Age Publishing Inc., Charlotte, NC, pp. 255-269.

Leithwood, K., Harris, A. and Hopkins, D. (2008), "Seven strong claims about successful school leadership", School Leadership \& Management, Vol. 28 No. 1, pp. 27-42.

Leydesdorff, L. (2007), “"Betweenness centrality” as an indicator of the "interdisciplinarity" of scientific journals", Journals of the American Society for Information Science and Technology, Vol. 58 No. 9, pp. 1303-1309.

Leydesdorff, L. and Bensman, S.J. (2006), "Classification and powerlaws: the logarithmic transformation", Journal of the American Society for Information Science and Technology, Vol. 57 No. 1, pp. 1470-1486.

Makel, M.C. and Plucker, J.A. (2014), "Facts are more important than novelty: Replication in the education sciences", Educational Researcher, Vol. 43 No. 6, pp. 304-316.

Moed, H.F. (2007), "The effect of "open access" on citation impact: An analysis of ArXiv's condensed matter section", Journal of the American Society for Information Science and Technology, Vol. 58 No. 13, pp. 2047-2054.

Moolenaar, N., Daly, A.J. and Sleegers, P.J.C. (2010), "Occupying the principal position: Examining relationships between transformational leadership, social network position, and schools' innovative climate", Educational Administration Quarterly, Vol. 46 No. 5, pp. 623-670.

Murphy, J., Vriesenga, M. and Storey, V. (2007), "Educational Administration Quarterly, 19792003: An analysis of types of work, methods of investigation, and influences", Educational Administration Quarterly, Vol. 43 No. 5, pp. 612628.

Narin, F., Carpenter, M. and Berlt, N.C. (1972), "Interrelationships of scientific journals", Journal of the American Society for Information Science, Vol. 23 No. 5, pp. 323-331.

Oplatka, I. (2009), "The field of educational administration: A historical overview of scholarly attempts to recognize epistemological identities, meanings and boundaries from the 1960s onwards", Journal of Educational Administration, Vol. 47 No. 1, pp. 8-35.

Oplatka, I. (2012), "Fifty years of publication: Pondering the legacies of the Journal of Educational Administration", Journal of Educational Administration, Vol. 50 No. 1, pp. 3456.

Polites, G.L. and Watson, R.T. (2009), "Using social network analysis to analyze relationships among IS Journals", Journal of the Association for Information Systems, Vol. 10 No. 8, pp. 595-636.

Price, D.J.D. (1965), "Networks of scientific papers", Science, Vol. 149, pp. 510-515.

Richardson, J.W. and McLeod, S. (2009), "Where should educational leadership authors publish to get noticed by the top journals in the discipline?" Educational Administration Quarterly, Vol. 45 No. 4, pp. 631-639.

Riehl, C. and Firestone, W.A. (2005), "What research methods should be used to study educational 
leadership?", in Firestone W.A. and Riehl C. (Eds.), A New Agenda for Research in Educational Leadership, Teachers College Press, New York, NY, pp. 156-170.

Riffel, J.A. (1986), "The study of educational administration: a developmental point of view",

Journal of Educational Administration, Vol. 24 No. 2, pp. 152-72.

Straus, R. (1973), "Department and disciplines: Stasis and change", Science, New Series, Vol. 182 No. 4115, pp. 895-898.

Rowan, B. (1995a), "Learning, teaching and educational administration: toward a research

agenda", Educational Administration Quarterly, Vol. 31 No. 3, pp. 344-54.

Sagan, C. (1997), The Demon-haunted World: Science as a Candle in the Dark, Ballantine Books, New York, NY.

Schneider, B., Carnoy, M., Kilpatrick, J., Schmidt, W.H. and Shavelson, R.J. (2007), "Estimating casual effects: Using experimental and observational designs", report from the Governing Board of the American Educational Research Association Grants Program, American Educational Research Association, Washington, DC.

Shavelson, R.J. and Towne, L. (2002), Scientific Research in Education, National Academy Press, Washington, DC.

Shwed, U. and Bearman, P.S. (2010), "The temporal structure of scientific consensus formation", American Sociology Review, Vol. 75 No. 6, pp. 817-840.

Thomas, A.R. (2012), "Succeed or else! Reflections on the $50^{\text {th }}$ anniversary of the Journal of Educational Administration", Vol. 50 No. 1, 12-33.

Wang, T.T., Lee, Y. and McLee, Y. (2011), "Invisible knowledge network of international marketing studies: Theory and evidence", Contemporary Management Research, Vo. 7 No. 1, pp. 67-85.

Wade, M., Biehl, M. and Kim, H. (2006), "Information system is not a reference discipline (and what we can do about it)", Journal of the Association for Information Systems, Vol. 7 No. 5, pp. 247-269.

Wasserman, S. and Faust, K. (1994), Social Network Analysis: Methods and Applications. Cambridge University Press, New York, NY.

Willower, D.J., \& Culbertson, J. (Eds) (1964), The Professorship in Educational Administration, University Council for Educational
Administration, Columbus, $\mathrm{OH}$, and the Pennsylvania State University, University Park, PA.

Zhao, L. (2014), "Riding the wave of open access: Providing library research support for scholarly publishing literary", Australian Academic \& Research Libraries, Vol. 45 No. 1, pp. 3-18.

Zitt, M. (2005), "Facing diversity of science: A challenge for bibliometric indicators", Measurement: Interdisciplinary Research and Perspectives, Vol. 3 No. 1, pp. 38-49. 
Appendix

Background Information of the Examined Journals in the Educational Administration Field

\begin{tabular}{|c|c|c|c|}
\hline $\begin{array}{l}\text { Journal } \\
\text { ID }\end{array}$ & Journal Name & $\begin{array}{l}\text { Included in } \\
\text { Analysis }\end{array}$ & Notes \\
\hline 1 & Educational Administration Quarterly & Yes & \\
\hline 2 & Journal of School Leadership & Yes & \\
\hline 3 & Educational Evaluation and Policy Analysis & Yes & \\
\hline 4 & Journal of Educational Administration & Yes & \\
\hline 5 & Economics of Education Review & Yes & \\
\hline 6 & Education Policy Analysis Archives & Yes & \\
\hline 7 & Journal of Educational Change & Yes & \\
\hline 8 & Educational Management, Administration \& Leadership & Yes & \\
\hline 9 & Educational Policy: An Interdisciplinary Journal of Policy and Practice & Yes & \\
\hline 10 & NASSP Bulletin & Yes & \\
\hline 11 & Journal of Cases in Educational Leadership & Yes & \\
\hline 12 & Improving Schools & Yes & \\
\hline 13 & Management in Education & Yes & \\
\hline 14 & Canadian Journal of Education & Yes & \\
\hline 15 & Educational Leadership & Yes & \\
\hline 16 & Educational Research and Reviews & Yes & \\
\hline 17 & AASA Journal of Scholarship and Practice & Yes & \\
\hline 18 & Online Journal of Distance Learning Administration & Yes & \\
\hline 19 & Journal for Critical Education Policy Studies & Yes & \\
\hline 20 & Canadian Journal of Educational Administration and Policy & Yes & \\
\hline 21 & Journal of Education Policy & Yes & \\
\hline 22 & International Journal of Leadership in Education: Theory into Practice & Yes & \\
\hline 23 & Urban Review: Issues and Ideas in Public Education & Yes & \\
\hline 24 & Education Economics & Yes & \\
\hline
\end{tabular}


Appendix continued

\begin{tabular}{|c|c|c|c|}
\hline $\begin{array}{l}\text { Journal } \\
\text { ID }\end{array}$ & Journal Name & $\begin{array}{l}\text { Included in } \\
\text { Analysis }\end{array}$ & Notes \\
\hline 25 & Educational Planning & Yes & \\
\hline 26 & International Studies in Educational Administration & Yes & \\
\hline 27 & School Effectiveness and School Improvement & Yes & \\
\hline 28 & Educational Assessment, Evaluation and Accountability & Yes & $\begin{array}{l}\text { The old name for the journal is } \\
\text { Journal of Personnel Evaluation } \\
\text { in Education. It was renamed as } \\
\text { Educational } \\
\text { Assessment, Evaluation and } \\
\text { Accountability on January 1, } \\
2008 \text {. }\end{array}$ \\
\hline 29 & International Journal of Educational Reform & Yes & \\
\hline 30 & Journal of Education Finance & Yes & \\
\hline 31 & School Leadership \& Management & No & Lacked access to 2013 issue 4 \\
\hline 32 & Journal of Higher Education Policy and Management & No & $\begin{array}{l}\text { Lacked access to } 2013 \text { issue } 2,3 \text {, } \\
4,5 \text {, and } 6\end{array}$ \\
\hline 33 & Leadership and Policy in Schools & No & $\begin{array}{l}\text { Lacked access to } 2013 \text { issue } 2,3 \text {, } \\
\text { and } 4\end{array}$ \\
\hline 34 & Journal of Educational Administration \& History & No & $\begin{array}{l}\text { Lacked access to 2011, 2012, and } \\
2013 \text { all issues }\end{array}$ \\
\hline 35 & Educational Horizons & No & No citations found \\
\hline 36 & Education Next: A Journal of Opinion \& Research & No & No citations found \\
\hline 37 & Policy Futures in Education & No & Lacked journal access \\
\hline 38 & Educational Leadership Review & No & Lacked journal access \\
\hline 39 & Journal of Women in Educational leadership & No & Ceased publication after 2010 \\
\hline 40 & The Next Educator & No & Lacked journal access \\
\hline 41 & The Australian Educational Leader & No & Lacked journal access \\
\hline 42 & National Association of Student Affairs Professional Journal & No & Lacked journal access \\
\hline
\end{tabular}


Appendix continued

\begin{tabular}{|c|c|c|c|}
\hline $\begin{array}{l}\text { Journal } \\
\text { ID }\end{array}$ & Journal Name & $\begin{array}{l}\text { Included in } \\
\text { Analysis }\end{array}$ & Notes \\
\hline 43 & Leading \& Managing: Journal of Australian Council for Education & No & Lacked journal access \\
\hline 44 & International Electronic Journal for Leadership in Learning & No & $\begin{array}{l}\text { Ceased publication from } 2010 \text { to } \\
\text { 2012, then reconstituted in } 2013 \\
\text { as the International Journal for } \\
\text { Leadership in Learning }\end{array}$ \\
\hline 45 & Academic Leadership: The Online Journal & No & $\begin{array}{l}\text { The journal now primarily } \\
\text { focuses on the publication of } \\
\text { student research within all } \\
\text { disciplines. The journal name } \\
\text { was changed to Academic } \\
\text { Leadership Journal in Student } \\
\text { Research. }\end{array}$ \\
\hline 46 & International Journal of Educational Advancement & No & Ceased publication after 2011 \\
\hline 47 & Journal of Access Policy \& Practice & No & Lacked journal access \\
\hline 48 & Journal of Research for Educational Leaders & No & $\begin{array}{l}\text { Ceased publication after March } \\
1,2009 .\end{array}$ \\
\hline
\end{tabular}

